\title{
Possible role of the gut microbiota in the pathogenesis of anorexia nervosa
}

\author{
Nobuyuki Sudo(D)
}

\begin{abstract}
Anorexia nervosa (AN), an eating disorder, is characterized by extreme weight loss and fear of weight gain. Psychosocial factors are thought to play important roles in the development and progression of AN; however, biological factors also presumably contribute to eating disorders. Recent evidence has shown that the gut microbiota plays an important role in pathogenesis of neuropsychiatric disorders including AN. In this article, we describe the possible role of the gut microbiota in the development and persistence of $\mathrm{AN}$, based on the latest research works, including those of our group.
\end{abstract}

Keywords: Anorexia nervosa, Eating disorder, Gut microbiota, Hyperactivity, Uremic toxin

\section{Introduction}

More than 1000 species of microbes are present in the human gut. They are collectively called the gut microbiota and are involved in various host functions [1-3]. Accumulated evidence suggests that gut microbes can play a role not only in regulating body weight [4] but also in the development and exacerbation of neuropsychiatric diseases [5-9].

Anorexia nervosa (AN) is an eating disorder characterized by extreme weight loss and a fear of weight gain $[10,11]$. In general, psychosocial issues are reported to play important roles in the pathology of AN [12-14]; however, biological factors are also presumed to contribute to this pathological process $[15,16]$. Recently, the gut microbiota has emerged as an important factor affecting AN pathogenesis.

In the first two sections of this article, we review a historical view that recognizes the commensal microbiota as an important factor affecting weight control and behavioral characteristics. Then, we discuss recent topics about this theme based on the latest research works,

Correspondence: sudo.nobuyuki.935@m.kyushu-u.ac.jp

Department of Psychosomatic Medicine, Graduate School of Medical Sciences, Kyushu University, 3-1-1 Maidashi, Higashi-ku, Fukuoka 812-8582, Japan



including those of our group. Unlike comprehensive systematic reviews and metanalyses $[17,18]$ that have been published recently, our aim is to use information from existing literature to generate testable hypotheses regarding the role of the gut microbiota in AN pathogenesis. By doing so, we hope to encourage researchers to conduct cause-effect studies about eating disorders based on realistic mechanistic hypotheses.

\section{Gut microbes exert a significant impact on body weight gain}

The fact that gut bacteria are involved in weight control and growth is not a novel finding, but is a long known basic theory in livestock industries. For example, antibiotics have often been used to promote livestock growth $[19,20]$, called antibiotic-induced growth promotion (AIGP). The use of antibiotics for AIGP is still being exploited in several countries, including the US and Japan. The precise mechanism for AIGP is unclear, but the fact that growth promotion is absent when administering antibiotics to germ-free animals deficient in bacteria $[21,22]$, indicates that the gut microbiota plays a critical role in this promoting effect [20]. Gordon et al. [23-25] used an elegant method of fecal transplantation to demonstrate that the gut microbiota is critically

(c) The Author(s). 2021 Open Access This article is licensed under a Creative Commons Attribution 4.0 International License, which permits use, sharing, adaptation, distribution and reproduction in any medium or format, as long as you give appropriate credit to the original author(s) and the source, provide a link to the Creative Commons licence, and indicate if changes were made. The images or other third party material in this article are included in the article's Creative Commons licence, unless indicated otherwise in a credit line to the material. If material is not included in the article's Creative Commons licence and your intended use is not permitted by statutory regulation or exceeds the permitted use, you will need to obtain permission directly from the copyright holder. To view a copy of this licence, visit http://creativecommons.org/licenses/by/4.0/ The Creative Commons Public Domain Dedication waiver (http://creativecommons.org/publicdomain/zero/1.0/) applies to the data made available in this article, unless otherwise stated in a credit line to the data. 
important for regulating body weight. Furthermore, another group [26] showed that transplantation of Christensenella minuta into mice with an obese phenotype suppressed weight gain. Thus, these findings indicate that the gut microbiota can affect body weight regulation by modulating the gut microbial ecology.

\section{Commensal microbes affect not only host stress response but also host behaviors}

When exposed to stress stimuli, the hypothalamicpituitary-adrenal (HPA) axis is activated to maintain homeostasis of the body [27]. Interestingly, the HPA axis is known to be affected by both genetic determinants and postnatal environmental factors during infancy [28, 29]. Because gut microbes are an important environmental factor, we hypothesized that the gut microbiota plays a role in host stress responses. In 2004, we first demonstrated that gut microbes determine the HPA response to stressors, using germ-free (GF) and gnotobiotic mice [30]. The degree of plasma ACTH and corticosterone elevation in response to 1 -h restraint stress was higher in GF mice than in specific pathogen free (SPF) mice. Furthermore, as summarized in Table 1, monoassociation with $B$. infantis, a representative inhabitant of the neonate gut, decreased the HPA stress response to SPF, while mono-association with Bacteroides vulgatus had no effect. The hormonal stress response of rabbit-derived enteropathogenic Escherichia coli (EPEC)monoassociated mice was substantially higher than that of GF mice, although such an exaggerated response was not found in mice with an EPEC mutant strain, $\triangle$ Tir [31], which was uninternalized due to defects in the translocated intimin receptor.

The finding that commensal bacteria can substantially affect the HPA stress response later in life raises an interesting question about whether gut bacteria can change host behavior. This question has been addressed

Table 1 Effects of restraint stress (RS) on plasma ACTH and the corticosterone levels of gnotobiotic mice

\begin{tabular}{|c|c|c|c|c|}
\hline & \multicolumn{2}{|c|}{ ACTH $(\mathrm{pg} / \mathrm{ml})$} & \multicolumn{2}{|c|}{ Corticosterone (ng/ml) } \\
\hline & Basal & $1 \mathrm{~h}-\mathrm{RS}$ & Basal & $1 \mathrm{~h}-\mathrm{RS}$ \\
\hline GF & $66 \pm 12$ & $188 \pm 16$ & $19 \pm 3.9$ & $131 \pm 12$ \\
\hline SPF & $54 \pm 6.1$ & $106 \pm 20^{* * *}$ & $21 \pm 6.5$ & $86 \pm 9.9^{* * *}$ \\
\hline B. infantis & $60 \pm 9.8$ & $113 \pm 15^{* * *}$ & $21 \pm 5.2$ & $79 \pm 9.5^{* * *}$ \\
\hline B. vulgatus & $63 \pm 9.9$ & $166 \pm 14$ & $17 \pm 6.8$ & $140 \pm 14$ \\
\hline EPEC & $49 \pm 15$ & $243 \pm 22^{*}$ & $19 \pm 6.6$ & $172 \pm 20^{*}$ \\
\hline$\Delta \mathrm{Tir}$ & $60 \pm 9.5$ & $153 \pm 25$ & $15 \pm 3.6$ & $102 \pm 17$ \\
\hline
\end{tabular}

Plasma ACTH and corticosterone levels were measured before or immediately after $1 \mathrm{~h}$ of RS in germ-free (GF), specific-pathogen-free (SPF), and gnotobiotic mice reconstituted with a single strain with Bifidobacterium infantis (B. infantis), Bacteroides vulgatus (B. vulgatus), rabbit-derived enteropathogenic E-coli (EPEC), or EPEC mutant strain ( $\triangle \mathrm{Tir}$ ) at 9 wks of age, as described previously [30]. *** $P<0.001$ and ${ }^{*} P<0.05$ (significantly different from the GF value) in the past decade by several independent groups, including our own [32-37]. The commensal microbiota is a crucial factor in modulating the host's behavioral profile. For example, we developed a reliable method to accurately analyze the behavior of GF mice maintained in an isolator [35]. This method enabled us to evaluate GF animal behavior without the risk of exposure to contamination. Using this system, GF mice were found to be more active and anxious than EX-GF mice that were transplanted with a normal SPF microbiota, based on open-field and marble-burying tests (Table 2). Colonization with $B$. infantis decreased the locomotor activity to the EX-GF level but had little effect on the anxiety levels. In contrast, mono-association with Clostridium coccoides reduced anxiety levels; however, it did not affect locomotor activity [35].

Collectively, these results indicate that gut microbiota can exert a substantial effect on the behavioral phenotype as well as the ability of the host to respond to stressors.

\section{Possible relation between gut microbiota and AN pathologies}

Patients with AN who have extremely low body weight often show marked resistance to weight gain in response to calorie intake; therefore, they usually require more calories to increase body weight than healthy subjects with normal weight [38-40]. Several factors such as increased physical activity [41] and diet-induced thermogenesis [42] are suggested to be involved in this phenomenon; however, the precise mechanisms for this are largely unknown. In addition, other important complications of AN include comorbid anxiety and depressive disorders. A well-known study, "the Minnesota Starvation Experiment" [43], which was performed during World War II, clearly showed that starvation significantly affected both physical and psychological conditions [43, 44]. Thirty-six volunteers who refused military service for religious reasons participated in this

Table 2 Transplantation of normal gut microbiota renders germ-free (GF) mice less active and anxious

\begin{tabular}{lllll}
\hline & & 7 wks of age & 10 wks of age & 16 wks of age \\
\hline GF & OFT (DT30) & $62.7 \pm 12.2$ & $63.7 \pm 9.4$ & $66.4 \pm 21.4$ \\
& MBT (NBM) & $14.3 \pm 5.3$ & $15.9 \pm 5.9$ & $14.6 \pm 6.2$ \\
EX-GF & OFT (DT30) & $46.5 \pm 7.1^{* * *}$ & $54.0 \pm 8.9^{* *}$ & $53.5 \pm 11.3^{*}$ \\
& MBT (NBM) & $12.5 \pm 5.8$ & $12.4 \pm 4.5^{*}$ & $9.5 \pm 5.5^{*}$ \\
\hline
\end{tabular}

Parent GF mice were transplanted with feces of SPF mice, and their offspring were used as EX-GF mice, as previously described [35]. GF and EX-GF mice at 7,10 and 16 wks of age were subjected to the open-field test (OPT) and marble-burying test (MBT). The total distance traveled for $30 \mathrm{~min}$ (DT30; meter) was automatically calculated as spontaneous locomotor activity. The number of marbles buried for $30 \mathrm{~min}$ (NBM) was counted as a parameter of anxiety-like behavior. All data are expressed as mean \pm SD. ${ }^{*} p<0.05$, ${ }^{* *} p<0.01$ and ${ }^{* * *} p<$ 0.001 (significantly different from the corresponding GF value) 
study. They were psychologically resilient before the experiment; however, most experienced periods of severe emotional distress during the study. This indicates that some psychiatric symptoms found in patients with AN could be explained by the effects of starvation. However, how and to what extent starvation affects the psychological and social functioning of patients with AN remain largely unknown.

Considering the emerging effects of gut microbes on body weight control or behavioral phenotypes, we speculated that commensal bacteria may play an important role in the onset and exacerbation of AN. Undoubtedly, patients' premorbid traits and psychosocial stressors are critical to the onset of AN. Prolonged physiological and psychological stress, including severe weight loss and extreme dietary habits, may influence the composition of the gut microbiota and subsequently induce "gut dysbiosis." This disturbed bacterial community may contribute to a decrease in food efficiency or behavioral abnormalities. For example, hyperactivity, one such abnormal behavior, may further strengthen the resistance to weight gain.

\section{Gut dysbiosis in patients with AN}

Several researchers have investigated whether gut dysbiosis exists in the gut of patients with $\mathrm{AN}$ and have shown that patients with AN show "dysbiosis", abnormal features of gut microbiota [45-48]. Armougom et al. [45] reported that Methanobrevibacter smithii was more frequently detected in patients with AN than those with low body weight due to diseases other than AN. Interestingly, these methanogenic archaea are often found in patients with constipation-predominant irritable bowel syndrome $[49,50]$. Mack et al. [47] found that the ratio of mucin-degrading bacteria to Clostridium cluster I, XI, and XVIII in an AN group was higher and the butyric acid-producing genus Roseburia was lower than that of the intestinal flora of normal body weight subjects. In addition, the proportion of Bacteroidetes phylum in patients with AN was significantly reduced compared to normal-weight subjects and did not recover after weight gain. Our group [48] used the intestinal bacterial analysis system YIF-SCAN ${ }^{\circ}$ that was developed by Yakult Central Laboratory to examine the intestinal bacteria of female subjects with AN and age-matched healthy women. The total bacterial, Clostridium coccoides, Clostridium leptum, Bacteroides fragilis, and Streptococcus counts were significantly lower in the AN group than the control group. The detection rate of the Lactobacillus plantarum subgroup was significantly lower in the AN group than in the control group. Based on 16S rRNA sequencing methods, we also reported a lower relative abundance of the phylum Bacteroidetes in patients with AN than healthy age-matched controls [51]. As summarized in Table 3, several recently published papers [52-57] have also shown changes in gut microbial ecology at the phylum or genus levels; however, no specific bacteria were identified among these reports. Thus, although the results differ depending on the patient's background or analytical methods, "gut dysbiosis" is consistently observed in patients with AN.

\section{Can gut dysbiosis contribute to AN pathologies: analyses using gnotobiotic animal models}

The existence of gut dysbiosis does not always relate to impaired functional outcomes; namely, such disturbed microbiota may not be a causal factor contributing to AN pathologies but an epiphenomenon resulting from lengthy starvation. To test this, we transplanted the gut microbiota of patients with AN into GF mice to establish gnotobiotic mice (gAN) whose microbiota consisted of the intestinal microbiota of patients with AN [51]. The gAN mice showed a significantly decreased weight gain compared with the gnotobiotic mice (gHC) transplanted with the gut microbiota of healthy women. Similarly, food efficiency (weight gain/food intake) was also lower in the gAN mice than in the gHC mice. Moreover, the gAN mice also exhibited increased anxiety-like behaviors relative to the $\mathrm{gHC}$ mice, when evaluated by open field and marble-burying tests. Interestingly, marble-burying behaviors displayed the highest correlation with the relative abundance of the genus Bacteroides. Moreover, the administration of Bacteroides vulgatus, which belongs to the genus Bacteroides and is a predominant species of the Bacteroides fragilis group in adult humans [58], reversed the behavioral abnormalities in the gAN mice.

These results indicate that some characteristic features of patients with $\mathrm{AN}$ can be reproduced by transplanting the AN gut microbiota. Bacteria, such as Bacteroides vulgatus, may play a protective role against the development of pathologies specific to patients with AN. Recently, Glenny et al. [59] reported that fecal transplantation from patients with AN exerted no significant effects on body weight in GF mice. A precise reason for this discrepant result is unclear; however, this may be related to the methodology of fecal transplantation, which involved the use of frozen feces, as they suggested. Therefore, the results of our study, which utilized fresh feces, should be validated by future experiments using a larger number of mouse colonies and different human donors.

\section{Molecules potentially involved in AN pathology: analyses using serum metabolome profiles}

The above results based on animal experiments provide valuable information about some pathological features of AN; nonetheless, they are inapplicable to human 
Table 3 Gut microbial composition of patients with anorexia nervosa (AN)

\begin{tabular}{|c|c|c|c|c|c|}
\hline Characteristics of AN participants & Methods & Main findings & ${ }^{1}$ Country & ${ }^{2}$ Year & ${ }^{3} \operatorname{Ref}$ \\
\hline AN $\left(n=9\right.$, age $19-36$ years, $\left.{ }^{4} \mathrm{BMl} 12.73 \pm 1.6\right)$ & ${ }^{5} \mathrm{PCR}$ & $\begin{array}{l}\text { Methanobrevibacter smithii concentration was higher in AN } \\
\text { patients than in lean control. }\end{array}$ & France & 2009 & {$[45]$} \\
\hline $\begin{array}{l}\text { AN }(n=14 \text {, age } 27.3 \pm 10.8 \text {, BMI median } \\
13.5)\end{array}$ & $P C R$ & $\begin{array}{l}\text { Firmicutes, Bacteridetes, Methanobrevibacter smithii, and E. coli were } \\
\text { found in } 98.5,67,64 \text { and } 51 \% \text { of the participants, respectively. }\end{array}$ & France & 2013 & {$[52]$} \\
\hline $\begin{array}{l}\text { AN }(n=16 \text {, Age } 28 \pm 11.7 \text { years, BMl } 16.2 \pm \\
1.5)\end{array}$ & ${ }^{6} 16 \mathrm{~S}$ rseq & $\begin{array}{l}\text { Alpha diversity was lower in AN patients than in healthy controls. } \\
\text { At genus level, Anaerostipes and Faecalibacterium were reduced } \\
\text { versus a healthy comparison group. }\end{array}$ & USA & 2015 & [46] \\
\hline $\begin{array}{l}{ }^{7} \text { ANR }(n=14, \text { Age } 28.1 \pm 10.7 \text { years, BMl } \\
12.7 \pm 1.5),{ }^{8} \text { ANBP }(n=11 \text {, Age } 32.5 \pm 9.4 \\
\text { years, BMl } 13 \pm 1.2)\end{array}$ & $P C R$ & $\begin{array}{l}\text { Amounts of Clostridium coccoides group, Clostridium leptum } \\
\text { subgroup, Bacteroides fragilis and Streptococcus were lower in AN } \\
\text { patients than in healthy controls. }\end{array}$ & Japan & 2015 & [48] \\
\hline $\begin{array}{l}\text { AN }(n=55 \text {, Age } 23.8 \pm 6.8 \text { years, BMl } 15.3 \pm \\
\text { 1.4) }\end{array}$ & 165 rseq & $\begin{array}{l}\text { The ratio of mucin-degrading bacteria to Clostridium cluster I, XI, } \\
\text { and XVIII was increased, while the butyric acid-producing genus } \\
\text { Roseburia was decreased, relative to controls. }\end{array}$ & Germany & 2016 & {$[47]$} \\
\hline AN $(n=15$, BMI $13.9 \pm 2.1)$ & $16 \mathrm{~S}$ rseq & $\begin{array}{l}\text { Enterobacteriaceae and Methanobrevibacter smithii levels were } \\
\text { increased compared with healthy controls; while, the genera } \\
\text { Roseburia, Ruminococcus and Clostridium, were depleted. }\end{array}$ & Italy & 2017 & {$[53]$} \\
\hline $\begin{array}{l}\text { AN }(n=18 \text {, Age } 22.4 \pm 3.2 \text { years, BMl } 15.3 \pm \\
\text { 1.3) }\end{array}$ & 165 rseq & $\begin{array}{l}\text { Only Coriobacteriaceaeone levels were significantly enriched in AN } \\
\text { compared to other groups. }\end{array}$ & Austria & 2017 & {$[54]$} \\
\hline $\begin{array}{l}\text { AN }(n=17 \text {, Age } 21.8 \pm 3.6 \text { years, BMl } 15.2 \pm \\
\text { 1.3) }\end{array}$ & 165 rseq & $\begin{array}{l}\text { Ruminococcaceae and Faecalibacterium were increased in a low- } \\
\text { zonulin population. No specific comments about AN. }\end{array}$ & Austria & 2018 & {$[55]$} \\
\hline AN $(n=33$, Age: $32 \pm 12$, BMl $11.7 \pm 1.5)$ & 165 rseq & $\begin{array}{l}\text { Klebsiella and Salmonella levels were more abundant in AN } \\
\text { patients whereas Eubacterium and Roseburia were significantly less } \\
\text { abundant in patients than controls. }\end{array}$ & France & 2019 & {$[56]$} \\
\hline $\begin{array}{l}\text { ANR }(n=10 \text {, Age } 25 \pm 2.8 \text { years, BMl } 13.3 \pm \\
0.3)\end{array}$ & 165 rseq & $\begin{array}{l}\text { A lower relative abundance of phylum Bacteroidetes was } \\
\text { observed in AN in comparison to age-matched healthy women. }\end{array}$ & Japan & 2019 & [51] \\
\hline
\end{tabular}

${ }^{1}$ Country, where each study was conducted; ${ }^{2}$ year, when each study was reported; ${ }^{3}$ ref, references number; ${ }^{4} \mathrm{BMI}$, body-mass index; ${ }^{5} \mathrm{PCR}$, polymerase chain reaction using targeted-bacteria specific primers; ${ }^{6} 16 \mathrm{~S}$ rseq, $16 \mathrm{~S}$ rRNA sequencing analysis; ${ }^{7} \mathrm{ANR}$, AN restricting-type; ${ }^{8} \mathrm{ANBP}$, AN binge-purging type

conditions. Therefore, we performed metabolome analyses using human materials.

\section{Uremic toxins and related compounds}

We detected 275 metabolites in serum samples from patients with AN and healthy controls [60]. Although the patients with AN enrolled in this study failed to show any apparent renal dysfunction, the serum levels of guanidinosuccinic acid and N2-phenylacetylglutamine, a uremic toxin, were significantly higher in the patients with AN restricting type (ANR). Therefore, precise quantification of uremic toxins was performed using selected-reaction monitoring of liquid chromatography/electrospray ionization-mass spectrometry/ mass spectrometry at Kureha Corporation, as reported [61-63]. The serum p-cresol (PCS), indole-3-acetic acid, and phenyl sulfate levels were significantly higher in an AN group than in an age-matched control group [60]. Because these uremic toxins are produced by gut microbes, gut microbes may contribute to increased uremic toxins. This possibility was supported by our results showing that serum PCS levels in an ANR group (but not a control group) correlated positively with the abundance of a Clostridium coccoides group or a Clostridium leptum subgroup [60].
Interestingly, in another cohort of ANR patients [51], the relative abundance of members of the genus Blautia was significantly higher in ANR patients than in age-matched healthy women. Previously, it was reported that the genus Blautia was the most abundant subgroup in human intestinal Clostridium coccoides group populations that were identified using the YIFSCAN system [64]. These findings suggest that increased populations of certain bacteria belonging to the genus Blautia may help elevate the serum uremic toxin levels of patients with ANR.

Yokoyama et al. [65] reported that PCS derived from gut microbes may slow the growth of weanling pigs and that inhibiting PCS production with antibiotics may be one of the mechanisms by which antibiotics can induce AIGP [20]. The compound was also found to play a role in the development and progression of neuropsychiatric diseases, such as autism [6668]. For example, Hsaio et al. [69] suggested that 4ethylphenylsulfate, a sulfated compound of PCS, may promote the development of autistic-like behavior in a mouse model with maternal immune activation. Nonetheless, whether PCS or its related compounds can affect weight gain and behavioral characteristics of patients with AN remains unclear. 
Amino acids: tryptophan and related molecules may be key players responsible for AN-specific pathologies

Serum metabolomic measurement showed another interesting finding regarding AN. Serum levels of 10 amino acids, including asparagine, tyrosine, isoleucine, alanine, histidine, leucine, methionine, proline, tryptophan (TRP), and valine, were lower in patients with AN than age-matched healthy women, when the falsediscovery rate corrected $p$-value was set at less than 0.1 . According to pathway enrichment analyses, the pathway of "phenylalanine, tyrosine, and TRP biosynthesis" was ranked as the highest impact score [60].

Since Kaye's pioneering works [70, 71], TRP has been demonstrated to play an important role in the development and maintenance of AN. In fact, in malnourished and emaciated individuals with AN, reduced plasma TRP availability [72-74] and reduced 5-hydroxyindoleacetic acid levels in the CSF have been reported [71]. This decreased serotonergic system may be involved in AN pathology by changing the host behavior. Indeed, increased locomotor activity, hyperactivity, is often seen in subjects with $\mathrm{AN}$ and has been regarded as a key characteristic of the disorder [75-77]. Interestingly, Uchida et al. [78] reported that mice fed TRP-limited diets exhibited increased locomotor activity. This indicates that a dearth of tryptophan due to decreased dietary intake can exacerbate ANspecific behavioral abnormalities, such as hyperactivity, via modulating the brain 5-HT system, subsequently aggravating poor weight gain by increasing exercise-induced calorie consumption. This series of events eventually forms a vicious cycle, which may substantially contribute to the perpetuation of AN pathology.

\section{Future perspectives}

Increasing attention has been paid to the role of gut microbiota in AN. However, in terms of gut microbes, the following questions remain to be addressed.

1) There is a pressing need to develop more effective therapeutics for adult patients with AN who are refractory to usual treatments. Probiotics may be a useful adjunctive therapy to achieve better weight gain and maintain appropriate mental conditions. This is clinically important and should be addressed by randomized controlled studies with large sample sizes.

2) Some gut bacteria metabolize indigestible dietary fiber or oligosaccharides and produce short chain fatty acids (SCFAs), such as acetate, propionate, and

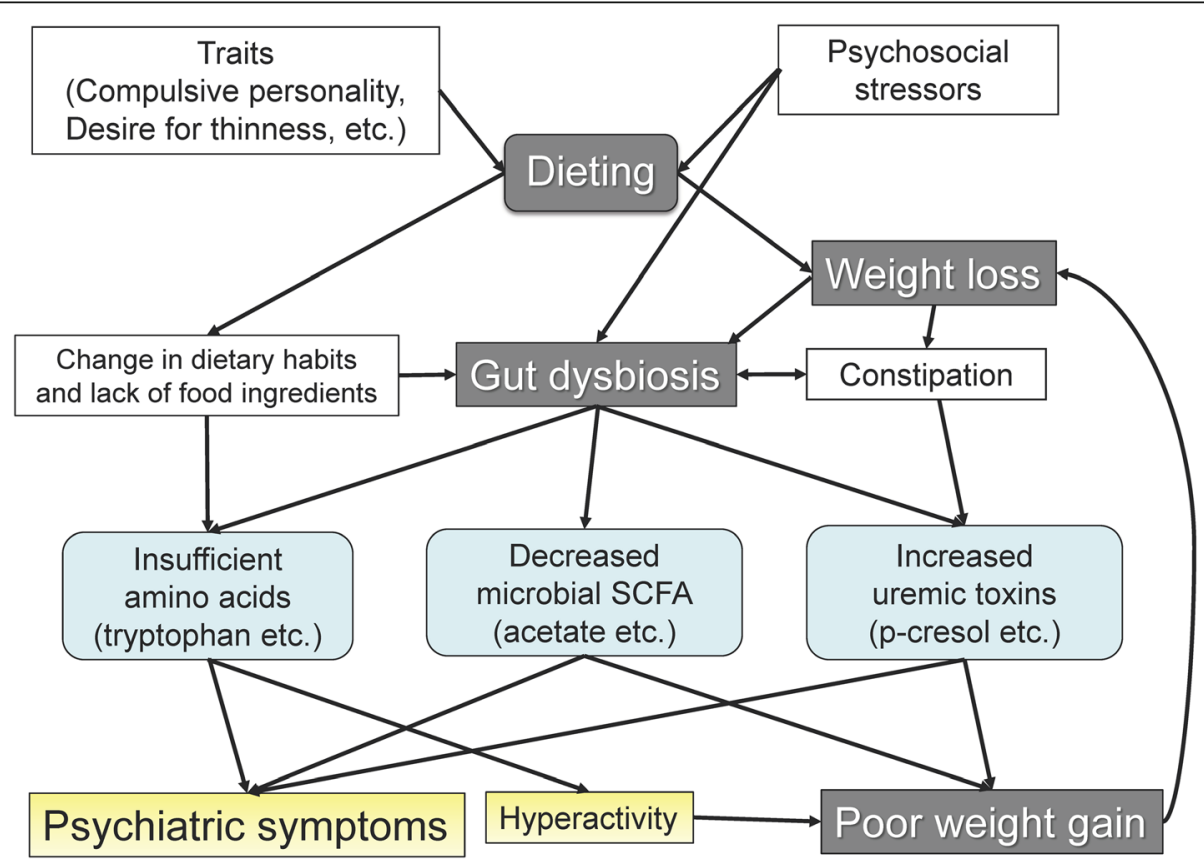

Fig. 1 Possible role of the gut microbiota in the pathogenesis of anorexia nervosa (AN). Premorbid traits, such as compulsive personality, perfectionism, and drive for thinness, and psychosocial stressors play a crucial role in AN development [74]. Consequently, changes in dietary habits and altered intake of food ingredients, induced by dieting, lead to a dearth of essential amino acids [60] and "gut dysbiosis" [45-48, 5156]. Physical and psychological stresses accompanying extreme weight loss may also affect the disturbed microbial ecology of the gut [89, 90]. Moreover, gut dysbiosis, together with the stresses, also induces constipation by impairing gut motility function [49, 50]. Prolonged constipation with gut dysbiosis elevates uremic toxins [60], such as p-cresol, which is possibly involved in poor weight gain [65] and psychiatric symptoms [69]. Decreased short chain fatty acids (SCFA), especially acetate, derived from gut dysbiosis [48] may also contribute to impaired weight control [79] and persistent anxiety [81, 82]. Finally, hyperactivity, a key characteristic of AN [75-77], is potentially induced by an insufficient intake of essential amino acids, such as tryptophan, and further perpetuates low body weight via increasing calorie expenditure 
butylate [79]. SCFAs are now considered to be one of the key molecules that can affect neuropsychiatric functions $[5,80]$. Such bacteriagenerated SCFAs exert an anxiolytic effect in mice [81, 82]; therefore, pre- or pro-biotic interventions that have an ability to increase fecal SCFAs may be a therapeutic option to improve mental conditions in patients with AN.

3) The majority of gut bacteria resides in the colon; therefore, the colonic bacteria have been extensively studied. However, how and to what extent microbes residing in the jejunum or ileum can contribute to host pathophysiology are largely unknown and should be clarified. For example, small intestinal bacterial overgrowth has been found to occur under some pathological conditions [83], and because amino acids, including tryptophan, are usually absorbed via transporters present in the upper GI tract $[84,85]$, it is theoretically possible that bacteria in the small intestine may play a role in the development and exacerbation of AN pathology by modulating the ability of the microbes to metabolize diet- or host-derived proteins. These bacteria may confer protection against $\mathrm{AN}$-specific behavioral abnormalities by producing amino acids such as tryptophan.

4) Recently, some species of gut microbes have been reported to synthesize d-amino acids as well as 1amino acids [86, 87]. D-serine is known to activate the N-methyl-D-aspartic acid receptor as its coagonist [88]. Therefore, D-amino acids, such as dtryptophan in the gut lumen, may exert a substantial effect on brain function similar to D-serine.

Figure 1 shows our working hypothesis concerning the possible role of the gut microbiota in the development and perpetuation of AN.

\section{Conclusion}

The theory of "autointoxication," which states that toxins generated in the gut exert a negative impact on brain function, inducing depression, anxiety, and other mental diseases [91-93], was long regarded as an irrational concept. Only recently has scientific research been conducted on the topic, and it has become extensively studied. Further developments in this field could elucidate the role of gut microbes in the pathogenesis of eating disorders and further provide a strong rationale for probiotic intervention as a treatment for patients with AN.

\section{Acknowledgements}

\section{Author's contributions}

NS wrote all sections of the manuscript and reviewed the final paper. The author read and approved the final manuscript.

\section{Funding}

This work was supported by KAKENHI Grants-in-Aid for Scientific Research on Innovative Areas "Will dynamics" (JP 16H06404: NS) and Scientific Research (B) (JP 20H04106: NS), as well as by a Grant-in-Aid from the Smoking Research Foundation (NS).

Availability of data and materials

Not applicable.

\section{Declarations}

Ethics approval and consent to participate

Not applicable.

Consent for publication

Not applicable.

Competing interests

The author (NS) declares no conflicts of interest associated with this manuscript.

Received: 7 August 2021 Accepted: 17 November 2021

Published online: 29 November 2021

\section{References}

1. Clemente JC, Ursell LK, Parfrey LW, Knight R. The impact of the gut microbiota on human health: an integrative view. Cell. 2012;148(6):1258-70. https://doi.org/10.1016/j.cell.2012.01.035

2. Lozupone CA, Stombaugh JI, Gordon Jl, Jansson JK, Knight R. Diversity, stability and resilience of the human gut microbiota. Nature. 2012;489(7415): 220-30. https://doi.org/10.1038/nature11550.

3. Nicholson JK, Holmes E, Kinross J, Burcelin R, Gibson G, Jia W, et al. Host-gut microbiota metabolic interactions. Science. 2012;336(6086):1262-7. https:// doi.org/10.1126/science.1223813.

4. Dabke K, Hendrick G, Devkota S. The gut microbiome and metabolic syndrome. J Clin Invest. 2019;129(10):4050-7. https://doi.org/10.1172/JCl1291 94.

5. Sampson TR, Debelius JW, Thron T, Janssen S, Shastri GG, Ilhan ZE, et al. Gut microbiota regulate motor deficits and neuroinflammation in a model of parkinson's disease. Cell. 2016;167:1469-80.e12. https://doi.org/10.1016/j. cell.2016.11.018.

6. Sharon G, Sampson TR, Geschwind DH, Mazmanian SK. The central nervous system and the gut microbiome. Cell. 2016;167(4):915-32. https://doi.org/1 0.1016/j.cell.2016.10.027.

7. Jiang $\mathrm{H}$, Ling Z, Zhang Y, Mao H, Ma Z, Yin Y, et al. Altered fecal microbiota composition in patients with major depressive disorder. Brain Behav Immun 2015:48:186-94. https://doi.org/10.1016/.bbi.2015.03.016.

8. Miyake S, Kim S, Suda W, Oshima K, Nakamura M, Matsuoka T, et al. Dysbiosis in the gut microbiota of patients with multiple sclerosis, with a striking depletion of species belonging to clostridia XIVa and IV clusters. PLoS One. 2015;10(9):e0137429. https://doi.org/10.1371/journal.pone.013742 9.

9. Tremlett H, Bauer KC, Appel-Cresswell S, Finlay BB, Waubant E. The gut microbiome in human neurological disease: a review. Ann Neurol. 2017; 81(3):369-82. https://doi.org/10.1002/ana.24901.

10. Zipfel S, Löwe B, Reas DL, Deter HC, Herzog W. Long-term prognosis in anorexia nervosa: lessons from a 21-year follow-up study. Lancet. 2000; 355(9205):721-2. https://doi.org/10.1016/S0140-6736(99)05363-5.

11. Zipfel S, Giel KE, Bulik CM, Hay P, Schmidt U. Anorexia nervosa: aetiology, assessment, and treatment. Lancet Psychiatry. 2015;2(12):1099-111. https:// doi.org/10.1016/S2215-0366(15)00356-9.

12. Treasure J, Claudino AM, Zucker N. Eating disorders. Lancet. 2010;375(9714): 583-93. https://doi.org/10.1016/50140-6736(09)61748-7.

13. Fairburn CG, Harrison PJ. Eating disorders. Lancet. 2003:361(9355):407-16. https://doi.org/10.1016/50140-6736(03)12378-1. 
14. Fairburn CG, Cooper Z, Doll HA, Welch SL. Risk factors for anorexia nervosa: three integrated case-control comparisons. Arch Gen Psychiatry. 1999;56(5): 468-76. https://doi.org/10.1001/archpsyc.56.5.468.

15. Couzin-Frankel J. Rethinking anorexia: challenging long-standing theories about the eating disorder, new research suggests biology is a powerful driver. Science. 2020;368(6487):124-7. https://doi.org/10.1126/science.368.64 87.124.

16. Schorr M, Miller KK. The endocrine manifestations of anorexia nervosa: mechanisms and management. Nat Rev Endocrinol. 2017;13(3):174-86. https://doi.org/10.1038/nrendo.2016.175.

17. Di Lodovico L, Mondot S, Doré J, Mack I, Hanachi M, Gorwood P. Anorexia nervosa and gut microbiota: a systematic review and quantitative synthesis of pooled microbiological data. Prog Neuro-Psychopharmacology Biol Psychiatry. 2021;106:110114. https://doi.org/10.1016/j.pnpbp.2020.110114.

18. Roubalová R, Procházková P, Papežová H, Smitka K, Bilej M, TlaskalováHogenová H. Anorexia nervosa: gut microbiota-immune-brain interactions. Clin Nutr. 2020;39(3):676-84. https://doi.org/10.1016/j.clnu.2019.03.023.

19. Moore PR, Evenson A. Use of sulfasuxidine, streptothricin, and streptomycin in nutritional studies with the chick. J Biol Chem. 1946;165(2):437-41. https://doi.org/10.1016/S0021-9258(17)41154-9.

20. Dibner JJ, Richards JD. Antibiotic growth promoters in agriculture: history and mode of action. Poult Sci. 2005;84(4):634-43. https://doi.org/10.1093/ps/ 84.4.634.

21. Coates M, Fuller R, Harrison G, Lev M, Suffolk S. A comparison of the growth of chicks in the Gustafsson germ-free apparatus and in a conventional environment, with and without dietary supplements of penicillin. Br J Nutr. 1963;17(1):141-50. https://doi.org/10.1079/BJN19630015.

22. Brown K, Zaytsoff SJM, Uwiera RRE, Inglis GD. Antimicrobial growth promoters modulate host responses in mice with a defined intestinal microbiota. Sci Rep. 2016;6(1). https://doi.org/10.1038/srep38377.

23. Turnbaugh PJ, Ley RE, Mahowald MA, Magrini V, Mardis ER, Gordon JI. An obesity-associated gut microbiome with increased capacity for energy harvest. Nature. 2006;444(7122):1027-31. https://doi.org/10.1038/na ture05414.

24. Ley R, Turnbaugh P, Klein S, Gordon J. Microbial ecology: human gut microbes associated with obesity. Nature. 2006;444(7122):1022-3. https:// doi.org/10.1038/nature4441021a.

25. Ridaura VK, Faith JJ, Rey FE, Cheng J, Duncan AE, Kau AL, et al. Gut microbiota from twins discordant for obesity modulate metabolism in mice. Science. 2013;341(6150):1241214. https://doi.org/10.1126/science.1241214.

26. Goodrich JK, Waters JL, Poole AC, Sutter JL, Koren O, Blekhman R, et al. Human genetics shape the gut microbiome. Cell. 2014;159(4):789-99. https://doi.org/10.1016/j.cell.2014.09.053.

27. Tsigos C, Chrousos GP. Hypothalamic-pituitary-adrenal axis, neuroendocrine factors and stress. J Psychosom Res. 2002;53(4):865-71. https://doi.org/10.1 016/S0022-3999(02)00429-4.

28. Francis D, Diorio J, Liu D, Meaney MJ. Nongenomic transmission across generations of maternal behavior and stress responses in the rat. Science. 1999;286(5442):1155-8. https://doi.org/10.1126/science.286.5442.1155.

29. Liu D, Diorio J, Tannenbaum B, Caldji C, Francis D, Freedman A, et al. Maternal care, hippocampal glucocorticoid receptors, and hypothalamicpituitary-adrenal responses to stress. Science. 1997;277(5332):1659-62. https://doi.org/10.1126/science.277.5332.1659.

30. Sudo N, Chida Y, Aiba Y, Sonoda J, Oyama N, Yu X-N, et al. Postnatal microbial colonization programs the hypothalamic-pituitary-adrenal system for stress response in mice. J Physiol. 2004;558(1):263-75. https://doi.org/1 0.1113/jphysiol.2004.063388.

31. Kenny B, DeVinney R, Stein M, Reinscheid D, Frey E, Finlay B. Enteropathogenic E. Coli (EPEC) transfers its receptor for intimate adherence into mammalian cells. Cell 1997;91:511-520, 4, https://doi.org/10.1016/ S0092-8674(00)80437-7.

32. Neufeld KM, Kang N, Bienenstock J, Foster JA. Reduced anxiety-like behavior and central neurochemical change in germ-free mice. Neurogastroenterol Motil. 2011;23(3):255-64. https://doi.org/10.1111/j.1365-2982.2010.01620.x.

33. Heijtz RD, Wang S, Anuar F, Qian Y, Bjorkholm B, Samuelsson A, et al. Normal gut microbiota modulates brain development and behavior. Proc Natl Acad Sci. 2011;108(7):3047-52. https://doi.org/10.1073/pnas.10105291 08.

34. Ezenwa VO, Gerardo NM, Inouye DW, Medina M, Xavier JB. Animal behavior and the microbiome. Science. 2012;338(6104):198-9. https://doi.org/10.1126/ science.1227412.
35. Nishino R, Mikami K, Takahashi H, Tomonaga S, Furuse M, Hiramoto T, et al. Commensal microbiota modulate murine behaviors in a strictly contamination-free environment confirmed by culture-based methods. Neurogastroenterol Motil. 2013;25(6):521-8. https://doi.org/10.1111/ nmo.12110.

36. Desbonnet L, Clarke G, Shanahan F, Dinan TG, Cryan JF. Microbiota is essential for social development in the mouse. Mol Psychiatry. 2014;19(2): 146-8. https://doi.org/10.1038/mp.2013.65.

37. De Palma G, Blennerhassett P, Lu J, Deng Y, Park AJ, Green W, et al. Microbiota and host determinants of behavioural phenotype in maternally separated mice. Nat Commun. 2015;6(1):7735. https://doi.org/10.1038/ ncomms8735.

38. Walker J, Roberts SL, Halmi KA, Goldberg SC. Caloric requirements for weight gain in anorexia nervosa. Am J Clin Nutr. 1979;32(7):1396-400, https://doi.org/10.1093/ajen/32.7.1396.

39. Weltzin TE, Fernstrom MH, Hansen D, McConaha C, Kaye WH. Abnormal caloric requirements for weight maintenance in patients with anorexia and bulimia nervosa. Am J Psychiatry. 1991;148(12):1675-82. https://doi.org/10.11 76/ajp.148.12.1675.

40. Marzola E, Nasser JA, Hashim SA, Shih PB, Kaye WH. Nutritional rehabilitation in anorexia nervosa: review of the literature and implications for treatment. BMC Psychiatry. 2013;13(1):290. https://doi.org/10.1186/1471-244X-13-290.

41. Kaye WH, Gwirtsman HE, Obarzanek E, George DT. Relative importance of calorie intake needed to gain weight and level of physical activity in anorexia nervosa. Am J Clin Nutr. 1988;47(6):989-94. https://doi.org/10.1 093/ajen/47.6.989.

42. Moukaddem M, Boulier A, Apfelbaum M, Rigaud D. Increase in diet-induced thermogenesis at the start of refeeding in severely malnourished anorexia nervosa patients. Am J Clin Nutr. 1997;66(1):133-40. https://doi.org/10.1 093/ajcn/66.1.133.

43. Keys A, Brožek J, Henschel A, Mickelsen O, Taylor HL. The biology of human starvation. Biol Hum Starvation. 1950;1 \& 2.

44. Kalm LM, Semba RD. History of nutrition they starved so that others be better fed: remembering Ancel Keys and the Minnesota experiment. J Nutr. 2005;135(6):1347-52. https://doi.org/10.1093/jn/135.6.1347.

45. Armougom F, Henry M, Vialettes B, Raccah D, Raoult D. Monitoring bacterial community of human gut microbiota reveals an increase in Lactobacillus in obese patients and methanogens in anorexic patients. PLoS One. 2009;4(9): e7125. https://doi.org/10.1371/journal.pone.0007125.

46. Kleiman SC, Watson HJ, Bulik-Sullivan EC, Huh EY, Tarantino LM, Bulik CM, et al. The intestinal microbiota in acute anorexia nervosa and during renourishment. Psychosom Med. 2015;77(9):969-81. https://doi.org/10.1097/ PSY.0000000000000247.

47. Mack I, Cuntz U, Grämer C, Niedermaier S, Pohl C, Schwiertz A, et al. Weight gain in anorexia nervosa does not ameliorate the faecal microbiota, branched chain fatty acid profiles, and gastrointestinal complaints. Sci Rep. 2016;6(1):26752. https://doi.org/10.1038/srep26752.

48. Morita C, Tsuji H, Hata T, Gondo M, Takakura S, Kawai K, et al. Gut dysbiosis in patients with anorexia nervosa. PLoS One. 2015;10(12):e0145274. https:// doi.org/10.1371/journal.pone.0145274.

49. Kim G, Deepinder F, Morales W, Hwang L, Weitsman S, Chang C, et al. Methanobrevibacter smithii is the predominant methanogen in patients with constipation-predominant IBS and methane on breath. Dig Dis Sci. 2012;57(12):3213-8. https://doi.org/10.1007/S10620-012-2197-1.

50. Ghoshal U, Shukla R, Srivastava D, Ghoshal U. Irritable bowel syndrome, particularly the constipation-predominant form, involves an increase in Methanobrevibacter smithii, which is associated with higher methane production. Gut Liver. 2016;10(6):932-8. https://doi.org/10.5009/GNL15588.

51. Hata T, Miyata N, Takakura S, Yoshihara K, Asano Y, Kimura-Todani T, et al. The gut microbiome derived from anorexia nervosa patients impairs weight gain and behavioral performance in female mice. Endocrinology. 2019; 160(10):2441-52. https://doi.org/10.1210/en.2019-00408.

52. Million M, Angelakis E, Maraninchi M, Henry M, Giorgi R, Valero R, et al. Correlation between body mass index and gut concentrations of Lactobacillus reuteri, Bifidobacterium animalis, Methanobrevibacter smithii and Escherichia coli. Int J Obes. 2013;37(11):1460-6. https://doi.org/10.1038/ IJO.2013.20

53. Borgo F, Riva A, Benetti A, Casiraghi MC, Bertelli S, Garbossa S, et al. Microbiota in anorexia nervosa: the triangle between bacterial species, metabolites and psychological tests. PLoS One. 2017;12(6):e0179739. https:// doi.org/10.1371/journal.pone.0179739. 
54. Mörkl S, Lackner S, Müller W, Gorkiewicz G, Kashofer K, Oberascher A, et al. Gut microbiota and body composition in anorexia nervosa inpatients in comparison to athletes, overweight, obese, and normal weight controls. Int J Eat Disord. 2017;50(12):1421-31. https://doi.org/10.1002/EAT.22801.

55. Mörkl S, Lackner S, Meinitzer A, Mangge H, Lehofer M, Halwachs B, et al. Gut microbiota, dietary intakes and intestinal permeability reflected by serum zonulin in women. Eur J Nutr. 2018;57(8):2985-97. https://doi.org/10.1007/ S00394-018-1784-0.

56. Hanachi M, Manichanh C, Schoenenberger A, Pascal V, Levenez F, Cournède $\mathrm{N}$, et al. Altered host-gut microbes symbiosis in severely malnourished anorexia nervosa (AN) patients undergoing enteral nutrition: an explicative factor of functional intestinal disorders. Clin Nutr. 2019;38(5):2304-10. https://doi.org/10.1016/J.CLNU.2018.10.004.

57. Skowron K, Kurnik-Łucka M, Dadański E, Bętkowska-Korpała B, Gil K. Backstage of eating disorder-about the biological mechanisms behind the symptoms of anorexia nervosa. Nutrients. 2020;12(9):1-32. https://doi.org/1 0.3390/NU12092604.

58. Ishikawa E, Matsuki T, Kubota H, Makino H, Sakai T, Oishi K, et al. Ethnic diversity of gut microbiota: species characterization of Bacteroides fragilis group and genus Bifidobacterium in healthy Belgian adults, and comparison with data from Japanese subjects. J Biosci Bioeng. 2013;116(2): 265-70. https://doi.org/10.1016/j.jbiosc.2013.02.010.

59. Glenny EM, Fouladi F, Thomas SA, Bulik-Sullivan EC, Tang Q, Djukic Z, et al. Gut microbial communities from patients with anorexia nervosa do not influence body weight in recipient germ-free mice. Gut Microbes. 2021; 13(1):1-15. https://doi.org/10.1080/19490976.2021.1897216.

60. Miyata N, Hata T, Takakura S, Yoshihara K, Morita C, Mikami K, et al. Metabolomics profile of Japanese female patients with restricting-type anorexia nervosa. Physiol Behav. 2021;228:113204. https://doi.org/10.1016/j. physbeh.2020.113204.

61. Kikuchi K, Itoh Y, Tateoka R, Ezawa A, Murakami K, Niwa T. Metabolomic search for uremic toxins as indicators of the effect of an oral sorbent AST120 by liquid chromatography/tandem mass spectrometry. J Chromatogr B Anal Technol Biomed Life Sci. 2010;878(29):2997-3002. https://doi.org/10.1 016/j.jchromb.2010.09.006.

62. Itoh Y, Ezawa A, Kikuchi K, Tsuruta Y, Niwa T. Protein-bound uremic toxins in hemodialysis patients measured by liquid chromatography/tandem mass spectrometry and their effects on endothelial ROS production. Anal Bioanal Chem. 2012;403(7):1841-50. https://doi.org/10.1007/s00216-012-5929-3.

63. Kikuchi $M$, Ueno $M$, Itoh $Y$, Suda $W$, Hattori M. Uremic toxin-producing gut microbiota in rats with chronic kidney disease. Nephron. 2017;135(1):51-60. https://doi.org/10.1159/000450619.

64. Kurakawa T, Ogata K, Matsuda K, Tsuji H, Kubota H, Takada T, et al. Diversity of intestinal Clostridium coccoides group in the Japanese population, as demonstrated by reverse transcription-quantitative PCR. PLoS One. 2015; 10(5):e0126226. https://doi.org/10.1371/journal.pone.0126226.

65. Yokoyama MT, Tabori C, Miller ER, Hogberg MG. The effects of antibiotics in the weanling pig diet on growth and the excretion of volatile phenolic and aromatic bacterial metabolites. Am J Clin Nutr. 1982;35(6):1417-24. https:// doi.org/10.1093/ajcn/35.6.1417.

66. Altieri L, Neri C, Sacco R, Curatolo P, Benvenuto A, Muratori F, et al. Urinary $\mathrm{p}$-cresol is elevated in small children with severe autism spectrum disorder. Biomarkers. 2011;16(3):252-60. https://doi.org/10.3109/1354750X.2010.54801 0.

67. Gabriele S, Sacco R, Cerullo S, Neri C, Urbani A, Tripi G, et al. Urinary p-cresol is elevated in young French children with autism spectrum disorder: a replication study. Biomarkers. 2014;19(6):463-70. https://doi.org/10.3109/13 54750X.2014.936911.

68. Persico AM, Napolioni V. Urinary p-cresol in autism spectrum disorder. Neurotoxicol Teratol. 2013;36:82-90. https://doi.org/10.1016/j.ntt.2012.09.002.

69. Hsiao EY, McBride SW, Hsien S, Sharon G, Hyde ER, McCue T, et al. Microbiota modulate behavioral and physiological abnormalities associated with neurodevelopmental disorders. Cell. 2013;155(7):1451-63. https://doi. org/10.1016/j.cell.2013.11.024.

70. Kaye WH, Barbarich NC, Putnam K, Gendall KA, Fernstrom J, Fernstrom M, et al. Anxiolytic effects of acute tryptophan depletion in anorexia nervosa. Int J Eat Disord. 2003;33(3):257-67. https://doi.org/10.1002/eat.10135.

71. Kaye WH, Gwirtsman HE, George DT, Jimerson DC, Ebert MH. CSF 5-HIAA concentrations in anorexia nervosa: reduced values in underweight subjects normalize after weight gain. Biol Psychiatry. 1988;23(1):102-5. https://doi. org/10.1016/0006-3223(88)90113-8.
72. Attia E, Wolk S, Cooper T, Glasofer D, Walsh BT. Plasma tryptophan during weight restoration in patients with anorexia nervosa. Biol Psychiatry. 2005; 57(6):674-8. https://doi.org/10.1016/j.biopsych.2004.11.045.

73. Schweiger U, Warnhoff M, Pahl J, Pirke KM. Effects of carbohydrate and protein meals on plasma large neutral amino acids, glucose, and insulin plasma levels of anorectic patients. Metabolism. 1986;35(10):938-43. https:// doi.org/10.1016/0026-0495(86)90058-2.

74. Kaye $W H$, Fudge $J$, Paulus M. New insights into symptoms and neurocircuit function of anorexia nervosa. Nat Rev Neurosci. 2009;10(8):573-84. https:// doi.org/10.1038/nrn2682.

75. Klein DA, Mayer LES, Schebendach JE, Walsh BT. Physical activity and cortisol in anorexia nervosa. Psychoneuroendocrinology. 2007;32(5):539-47. https://doi.org/10.1016/j.psyneuen.2007.03.007.

76. Hebebrand J, Exner C, Hebebrand K, Holtkamp C, Casper RC, Remschmidt H, et al. Hyperactivity in patients with anorexia nervosa and in semistarved rats: evidence for a pivotal role of hypoleptinemia. Physiol Behav. 2003;79(1): 25-37. https://doi.org/10.1016/S0031-9384(03)00102-1.

77. Scheurink AJW, Boersma GJ, Nergårdh R, Södersten P. Neurobiology of hyperactivity and reward: agreeable restlessness in anorexia nervosa. Physiol Behav. 2010;100(5):490-5. https://doi.org/10.1016/j.physbeh.2010.03.016.

78. Uchida S, Kitamoto A, Umeeda H, Nakagawa N, Masushige S, Kida S. Chronic reduction in dietary tryptophan leads to changes in the emotional response to stress in mice. J Nutr Sci Vitaminol. 2005;51(3):175-81. https:// doi.org/10.3177/jnsv.51.175.

79. Hernández MAG, Canfora EE, Jocken JWE, Blaak EE. The short-chain fatty acid acetate in body weight control and insulin sensitivity. Nutrients. 2019; $11(8): 1943$. https://doi.org/10.3390/nu11081943.

80. Erny D, De Angelis ALH, Jaitin D, Wieghofer P, Staszewski O, David E, et al. Host microbiota constantly control maturation and function of microglia in the CNS. Nat Neurosci. 2015;18(7):965-77. https://doi.org/10.1038/nn.4030.

81. Kimura-Todani T, Hata T, Miyata N, Takakura S, Yoshihara K, Zhang XT, et al. Dietary delivery of acetate to the colon using acylated starches as a carrier exerts anxiolytic effects in mice. Physiol Behav. 2020;223:113004. https://doi. org/10.1016/j.physbeh.2020.113004.

82. van de Wouw M, Boehme M, Lyte JM, Wiley N, Strain C, O'Sullivan O, et al. Short-chain fatty acids: microbial metabolites that alleviate stress-induced brain-gut axis alterations. J Physiol. 2018;596(20):4923-44. https://doi.org/1 $0.1113 / J P 276431$.

83. Quigley E, Murray J, Pimentel M. AGA clinical practice update on small intestinal bacterial overgrowth: expert review. Gastroenterology. 2020;159(4): 1526-32. https://doi.org/10.1053/J.GASTRO.2020.06.090.

84. Singer D, Camargo SMR, Ramadan T, Schäfer M, Mariotta L, Herzog B, et al. Defective intestinal amino acid absorption in Ace2 null mice. Am J Physiol Gastrointest Liver Physiol. 2012;303(6):G686-95. https://doi.org/10.1152/A JPGI.00140.2012.

85. Hashimoto T, Perlot T, Rehman A, Trichereau J, Ishiguro H, Paolino M, et al. ACE2 links amino acid malnutrition to microbial ecology and intestinal inflammation. Nature. 2012;487(7408):477-81. https:/doi.org/10.1038/NATURE11228.

86. Matsumoto M, Kunisawa A, Hattori T, Kawana S, Kitada Y, Tamada H, et al. Free D-amino acids produced by commensal bacteria in the colonic lumen. Sci Rep. 2018;8(1):17915. https://doi.org/10.1038/s41598-018-36244-z.

87. Kawase T, Nagasawa M, Ikeda H, Yasuo S, Koga Y, Furuse M. Gut microbiota of mice putatively modifies amino acid metabolism in the host brain. $\mathrm{Br} J$ Nutr. 2017;117(6):775-83. https://doi.org/10.1017/S0007114517000678.

88. Mothet J, Parent A, Wolosker $\mathrm{H}$, Brady R, Linden D, Ferris C, et al. D-serine is an endogenous ligand for the glycine site of the $\mathrm{N}$-methyl-D-aspartate receptor. Proc Natl Acad Sci U S A. 2000;97(9):4926-31. https://doi.org/10.1 073/PNAS.97.9.4926

89. Bailey MT, Coe CL. Maternal separation disrupts the integrity of the intestinal microflora in infant rhesus monkeys. Dev Psychobiol. 1999;35:14655. https://doi.org/10.1002/(SICI)1098-2302(199909)35:2\&lt;146::AIDDEV7\&gt;3.0.CO;2-G

90. Holdeman LV, Good IJ, Moore WEC. Human fecal flora: variation in bacterial composition within individuals and a possible effect of emotional stress. Appl Environ Microbiol. 1976;31(3):359-75. https://doi.org/10.1128/a em.31.3.359-375.1976.

91. Brower DR. Auto-intoxication in its relations to the diseases of the nervous system. J Am Med Assoc. 1898;30(11):575-7. https://doi.org/10.1001/jama.1 898.72440630001001.

92. Schmidt C. Mental health: thinking from the gut. Nature. 2015;518(7540): S12-5. https://doi.org/10.1038/518S13a. 
93. Bested AC, Logan AC, Selhub EM. Intestinal microbiota, probiotics and mental health: from Metchnikoff to modern advances: part I -

autointoxication revisited. Gut Pathog. 2013;5(1):5. https://doi.org/10.1186/1 757-4749-5-5.

\section{Publisher's Note}

Springer Nature remains neutral with regard to jurisdictional claims in published maps and institutional affiliations.

Ready to submit your research? Choose BMC and benefit from:

- fast, convenient online submission

- thorough peer review by experienced researchers in your field

- rapid publication on acceptance

- support for research data, including large and complex data types

- gold Open Access which fosters wider collaboration and increased citations

- maximum visibility for your research: over $100 \mathrm{M}$ website views per year

At $\mathrm{BMC}$, research is always in progress.

Learn more biomedcentral.com/submissions 